\title{
FORMATION OF INFORMATION COMPETENCE IN LITERATURE LESSONS BY NEXT-GENERATION
}

\section{ФОРМУВАННЯ ІНФОРМАЦІЙНОЇ КОМПЕТЕНТНОСТІ НА УРОКАХ ЛІТЕРАТУРИ ЗАСОБАМИ ІКТ НОВОГО ПОКОЛІННЯ}

\author{
Svitlana Palamar ${ }^{1}$ \\ Lydmila Nazarenko ${ }^{2}$
}

DOI: https://doi.org/10.30525/978-9934-588-38-9-13

\begin{abstract}
The article actualizes the need to change the content and the training tools, in accordance with the challenges of today, to use the strategy for new types of ICTs and to avoid the psychological and psychological barriers that arise in the practical use of Internet resources, to form the information competence of the recipients. The content of the concept of «information competent person» has been clarified. The pedagogical approaches and conditions under which the formation of informational competence of schoolchildren will be successful and which allow creation of favorable educational environment for emotional, cognitive, volitional development of youth are offered. The essence and structure of information competence are characterized. The methodical system of formation of information competence of students with the purpose of acquisition of their value-moral orientations is elucidated. It is stated that in the formation of information competence, consideration of methodological and technological factors plays a significant role. To prepare a modern student for life in society, one must take into account his individual capabilities, abilities, willingness to use IT. Forming key competences in students requires some innovation in the educational process. Therefore, it is necessary to limit the amount of uncontrolled use of digital technology and to learn how to use ICT tools according
\end{abstract}

\footnotetext{
${ }^{1}$ Candidate of Pedagogical Sciences, Senior Researcher,

Deputy Director for Scientific Work at the Pedagogical Institute,

Boris Grinchenko University of Kyiv, Ukraine

${ }^{2}$ Candidate of Pedagogical Sciences,

Senior Lecturer of the Theory and Methods of Preschool and Primary Education,

Mykolayiv Regional Institute of Postgraduate Education, Ukraine

(C) Svitlana Palamar, Lydmila Nazarenko
} 
to the purpose and objectives of the educational process, with the priority being given to the health-saving component of education. Therefore, there is an urgent need for further development of ICT-enabled education. The importance of combining blended and online learning in and out of literature is substantiated. Possibilities of introduction of new types of ICT in education, their peculiarities of application are characterized. Offered in the course of experiential learning literature assignments using online resources («LearningApps», «Prezi», «Emaze», «PoowToon», «Kizoa», «Padlet», «Thinglink», «Piktochart», «Tagul», «Canva», «Realtimeboard», «Mindmeister», «Mindomo», «Ilovefreesoftware», «Zaption») for the purpose of analysis, interpretation of works of art taking into account the peculiarities of their genre and generic specificity. The importance of using iGoogle's search engine learners to be used during self-study. The cross-cutting skills of high school students, which contribute to the acquisition of IR, allow working in standard and changed conditions. The use of Internet resources for the purpose of forming the information competence of high school students in literature classes in a structured form is presented, their possibilities and practical orientation of tasks for improving the quality of education due to the updating of the content of education are taken into account. The components, criteria, indicators and levels of ICT competence have been identified, which have an impact on the development of students in various fields of activity. Modern forms of organization of work with students on the basis of ICT with the use of innovative teaching methods are offered. The conditions of organization of educational activity of schoolchildren by which the learning became successful are investigated. The results of the empirical study among schoolchildren of general educational institutions are generalized.

\section{1. Вступ}

Актуальність дослідження. Молоде покоління зростає в умовах інформаційного суспільства, залюбки використовує соціальні мережі для спілкування, іноді крокує попереду своїх учителів у використанні інформаційних сервісів, гаджетів. Освіта не стоїть на місці, постійно відбуваються зрушення в кращий бік, модернізація. Теперішній розвиток інформаційних технологій надає можливість навчати медійне покоління школярів, використовуючи види сучасних IКТ, зокрема 
Smart-технології, хмарні технології, Web Syndication, Second Life, геосервіси, технології Web 3.0 (мобільні технологіï). Наша освітня система лише частково готова до їхнього впровадження, оскільки відсутне навчальне забезпечення, програми й підручники з літератури не містять пропозицій і завдань, які передбачали б використання нових засобів ІКТ, учителі опановують нові технології переважно самотужки й спостерігається хаотичне використання хмарних технологій. Таке навчання потребує розробки методичного забезпечення (програм, підручників), підготовки спеціалістів, готовності учнів, цілесп-рямованих змін у освіті, відповідно до викликів сьогодення. Зв'язок старшокласників 3 мережею Інтернет відбувається постійно, він $є$ джерелом інформації. Існують прибічники такого спілкування, $\epsilon$ й опоненти, але діти не люблять заборон, краще, коли їхню зацікавленість спрямовують у русло електронного (Е) навчання, це розкриватиме потенціал школярів, сприятиме визнанню їхнього інтелектуального розвитку, сприятиме вдосконаленню освітнього процесу.

Мета дослідження. Висвітлити зміст електронного навчання, яке дає змогу кожному учневі стати співавтором уроку з використанням IКТ, розкрити особливості використання Е-ресурсів у шкільній практиці в процесі викладання української літератури для особистісного професійного зростання учнів, учителів, студентів педагогічних вузів, а також максимального забезпечення якості освіти; з'ясувати зміст поняття «інформаційно-компетентна особистість».

\section{2. Постановка проблеми}

Компетентний випускник школи, вузу стає бажаним об'єктом для робо-тодавця, оскільки останні шукають кваліфікованих, обізнаних, мобільних, гнучких працівників. Щоб бути конкурентноспроможними на ринку труда, необхідно володіти новими інформаційними засобами, діяти в програмованому середовищі, але не завжди в школярів сформована інформаційна компетентність на високому рівні, оскільки їхні вчителі стикаються з рядом проблем, що стосуються вибору сервісів для роботи, браком розробленої методики навчання, володіють недостатнім рівнем знань у області інформаційно-комунікаційних технологій (IКТ) нового покоління. Їхній авторитет як професіоналів знижується, з'являється недовіра школярів. Це свідчить про потребу 
сприймати віртуальну реальність і використовувати іiі можливості, навчання не лише учнів, а й їхніх наставників без прив'язки до робочого місця.

Крім того, виникають психологічні бар'єри в учителів щодо застосування нових технологій, оскільки багато з них звикли працювати по-старому. Потреба в не пасивних користувачах мережі Інтернет, а активних діячах, для яких комп'ютер виступає універсальним порадником, вчителем, що вимагає тривалого навчання в оволодінні його можливостями, у виробленні навичок користування цим засобом, зростає. Цілком природно, що в ході використання IКТ необхідно долати негативне ставлення колег, підвищувати обізнаність, комп’ютерну грамотність, медіаграмотність, медіакультуру вчителів, навчати їх орієнтуватися в педагогічних мережних співтовариствах. Актуальність статті зумовлена також потребою в уникненні спротиву й психологічних бар'єрів, які виникають, здійсненні самонавчання не лише кожній окремій особистості, а й через їхню участь у діяльності в глобальній мережі, завдяки чому освіта стане тим чинником, що розкриє потенціал людини через самовдосконалення, працю, досвід, мислення.

\section{3. Аналіз останніх досліджень і публікацій}

Наукова думка постійно збагачується новими розробками. Формування інформаційної компетентності перебуває в колі уваги як вітчизняних учених (Баловсяк Н., Родигіна I., Савченко 3.) [1; 2; 3], так і зарубіжних (Андресен Б. (Швеція) [4], Ваннер Т. (Австралія) [5], Зубарев К. [6], Лебедєва М. (Росія) [7], Ванкель Ч. (США), Кінгслей Я. (Іспанія) [8], Сіменс Г. (Канада) [9], Сіменсон М. [10], Хейніх Р. (США) [11]).

На важливості впровадження Е-навчання, хмарних технологій (технології обробки даних, в яких комп'ютерні ресурси надаються інтернет-користувачу як он-лайн-сервіси) у систему освіти та роботі на різних платформах, що дають змогу застосовувати, зберігати великі обсяги інформації, працювати з гіпертекстом, створювати єдиний інформаційний простір із метою проведення учнівських конференцій, on-line-змагань засвідчують Ч. Субраманьян (Канада) [12], Н. Султан (Великобританія) [13, с. 109]. Використання Е-навчання як педагогічної практики Системи дистанційного навчання України застосовували В. Кухаренко В. Нестеренко, Н. Решетник, М. Сіренко, Л. Товажнянський [14]. 
На використанні інтелектуальних навчальних середовищ (Intelligent Learning Environments, ILEs) та інтелектуальних навчальних комплексів (Intelligent Learning Environments, ILEs), що «спрямовані на індивідуалізоване навчання», зосереджують увагу К. Кабассі, М. Вірву (Ісландія) [15].

Проблема становлення інформаційно компетентної (IК) особистості поступово утверджується як визначальна в сучасній філософії освіти та педагогіці. Провідним у формуванні ІК є перехід від накопичення знань до вміння працювати з інформацією. Г. Сіменс стверджує, що учні мають уміти працювати з інформацією й поза навчальним процесом, оскільки освіта має бути безперервною [9]. ІК як знання, уміння добувати, опрацьовувати та використовувати інформацію з різних джерел подає I. Родигіна [2, с. 37]. На думку Е. Морковіної, ІК динамічна, передбачає функціонування, отже, постійні зміни та розвиток; безпосередньо у властивостях, зв'язках, функціях та в їхній взаємодії полягає джерело розвитку інформаційної компетентності як цілісної системи. ІК - це інтегративна якість особистості, що характеризується ступенем засвоєння сукупності компетенцій, необхідних для орієнтації та діяльності в інформаційному просторі [16, с. 22]. Розуміємо особистість, яка здатна до організації нових форм співпраці з іншими людьми на базі мікропроцесорної техніки, різних видів діяльності, підготовлена до життя в соціумі, обізнана з ІКТ, методами обробки інформації, спроможна удосконалювати свою діяльність, що спиратиметься на сукупність професійних, методологічних, загальнокультурних знань та практичних умінь, є інформаційно компетентною.

Важливості набувають не самі знання як багаж, а вміння за потреби знайти їх і скористатися ними. У своїй книзі Ч. Ванкель і Я. Кінгслей пропонують друге життя для педагогів у навчанні (Second Life and Education). Вони представляють популярну платформу, яку безкоштовно відвідати може кожний. На ній навчають досягати результатів, приймати рішення в умовах реального часу. Автори переконані, що віртуальний світ надає переваги й більш широкий спектр для перспектив у навчанні [8, с. 14]. Учені пропагують безперервну освіту, яка змінює поведінку реципієнтів через стимули й знаходження сенсу в електронному навчанні в мережі, яке є більш демократичним. 
Позитивним стає поєднання форм традиційного й інноваційного навчання. На значущості поєднання змішаного і он-лайн навчання вказує Т. Ваннер, з його погляду, необхідно навчатися протягом усього життя. Що унікальне в сервісному навчанні, так це те, що воно пропонує пряме застосування теоретичних моделей [5, с. 115]. Учений вважає за потребу розміщувати знахідки на блогах, інтернет-форумах. Така активна самоосвіта сприяє тому, що учні без допомоги проводять дослідження, які пропонує викладач. Це означає, що реципієнти не обмежуються питаннями й відповідями, вони використовують здобуті знання на практиці, у розвідках, розглядають важливі теми з різних боків, користуючись раніше отриманим багажем знань, умінь, ставлень, поглядів.

Активні можливості в освіті, з погляду Е. Портера, збільшують вплив професійного розвитку вчителя [17, с. 82]. Становлення викладача, його зростання залежить від глибокого розуміння потреб сьогодення, перспектив і пріоритетів, уміння самостійно використовувати сервіси, навчати школярів досягати спільної мети через залучення сучасних IKT.

На важливості забезпеченні належних умов для навчання з боку вчителів в умовах глобалізації та інтернаціоналізації освіти з метою набуття широкого спектру навичок працювати он-лайн наполягають С. Кайе i Ш. Харпер [18]. Service-learning, на думку ряду авторів, розширює можливості навчання, оскільки виходить за межі академічного терміна; це закладає основу для постійного особистісного зростання протягом всього періоду отримання освіти і після нього [19]. Такі роздуми свідчать про потребу розробки стратегії навчання на тривалий час, самовдосконалення, самоосвіти й саморозвитку з боку суб'єктів навчання.

Е-навчання В. Биков і В. Кухаренко розуміють як форму, що існує у вигляді комплексу певних прояв педагогічних, інформаційно-комунікаційних, еволюційних, дистанційних та інших технологій, цінного навчання [20]. Вони забезпечують краще сприймання інформації, інтегрують знання з різних предметів, поєднують технологію і творчість, уможливлюють створення мобільного простору, який об'єднує роботу в школі й дома.

Спостерігаємо впровадження нових видів ІКТ в освіті, зокрема Smart-технологій, завдяки використанню інтерактивних дошок, мобільних телефонів, айфонів, Smart TV. У той же час хмарні техно- 
логії слугують для обробки даних, в яких комп'ютерні ресурси надаються Інтернет-користувачеві як он-лайн сервіс, пропонують масштабовану інфраструктуру й не залежать безпосередньо від комп'ютера. Використання гул-додатків, якісних сервісів дає змогу познайомити учнів 3 можливостями колаборації, виявом аналітико-синтетичної діяльності й моделювання, розкрити творчі здібності школярів, реалізувати їхні задуми, швидше проходити соціалізацію. Web Syndication надає перспективу в поширюванні аудіо і відеоконтентнтів на будьяких сайтах, передбачає партнерські зв'язки. Second Life відомий як тривимірний віртуальний світ, що має елементи соціальних мереж. У ньому можна вмикати інтернет-трансляцію радіостанцій, слухати музику, переглядати фільми й відео, грати в ігри, брати участь у житті он-лайнових спільнот. Геосервіси (Google Earth) розвивають світогляд, оскільки дають змогу будувати віртуальні карти й подорожувати світом. Щодо Web 3.0, то ця концепція розвитку інтернет-технологій була розроблена й обгрунтована Дж. Калаканісом, вона пропонує більш якісний контент і уможливлює іiі використання як очно, так і дистанційно. Web 3.0 - персональний сайт, який може бути переносним. Biн характеризується зосередженістю на особистості, іiї можливостях. Web 3.0, на думку О. Болдачева, - це безліч онлайн-сервісів, що надають повний спектр засобів внесення, редагування, пошуку й відображення будь-якого типу контенту, який одночасно забезпечує онтологізацію діяльності користувачів, а через неї і його самого. У ході розвитку технології важливим стає не сайт, а результат діяльності реципієнта в мережі [21]. До того ж колективне наповнювання контенту уможливлює розширення світогляду, дає змогу поділитися досвідом, передбачає плюралізм думок. На сьогодні не важливо, де він розміщений, оскільки на перший план виходить людина зі своєю позицією, переконаннями, поглядами й відображенням інформаційної компетентності. Усі ці види сучасних ІКТ не є сумою технологій, кожен з них може бути використаний за потреби в певний момент завдяки партнерській узаємодії вчителя й учня.

Важливого значення для опанування літературою $є$ знання тексту твору, уміння здійснювати аналітико-синтетичну діяльність над ним, структурувати власне висловлювання, тому набуває актуальності участь у змішаному навчанні (очному / дистанційному, традицій- 
ному / інноваційному), проектах, створенні власних веб-сайтів, що слугує значною допомогою в осмисленні мистецтва слова, дає змогу продемонструвати свою позицію щодо прочитаного. Такі особистісні риси як: уміння працювати в команді, планувати, передбачати наслідки, проектувати, моделювати, досягати результату, корегувати власну діяльність стають більш значущими, ніж набір знань, яким володіє учень 3 певного предмета, але не завжди вони є сформованими в підростаючого покоління.

Щоб брати участь у обговоренні прочитаного, потрібно бути обізнаним у царині літератури. Можливість спілкуватися з однодумцями, які знаходяться на далекій відстані не заради гри, знайомитися 3 новими людьми для отримання порад і знань від звичайного вчителя й до професора, не зазнаючи при цьому значних фінансових витрат і моральних незручностей, дарує відчуття соціальної значущості й мотивує до саморозвитку й самовдосконалення, а засоби IКТ стимулюють пізнання. Уміння синтезувати інформацію, встановлювати причиново-наслідкові зв'язки, узаємозв'язки, бачити спільне й відмінне в ідеях і концепціях, робити висновки потрібні нам щоденно, тому вартісними є не самі знання, а процес їх надбання. Чим більш значущою буде інформаційна компетентність учня і його робота на власному вебсайті, тим більшого поширення вона набуде й здобуде визнання.

Текст / медіатекст стає інструментом для створення своєрідного інформаційного колажу. Його розташування відбувається за принципом лайфстрім (lifestream): постійного потоку інформації у вигляді щоденника, що дає можливість генерувати об'єкти в певній послідовності, об'єднувати їх у групи (сторінки), структурувати за змістом. Система сучасного веб-сайту дає змогу довантажувати сторінки без їхнього оновлення, а технологія тегів - переглядати з будь-якого пристрою, що має доступ до мережі Інтернету. Оновлення інформації зацікавлює, викликає бажання творити й мотивує до діяльності. Базою для Web 3.0 залишаються найкращі сервіси Web 2.0. Пошуковий механізм - iGoogle дає змогу школярам ознайомитися з Google Toolbar - панеллю інструментів для браузерів, Google Chrome - сучасним веб-браузером та його додатками: хмарними зберігачами Googleдиск та WebFile; веб-дизайном, сайтами, спрямованими на полегшення роботи в Інтернеті, створення й редагування аудіо і відео, швидку 
розсилку листів, обробку фотографій, побудову графіків. Зокрема використання Timetoast дає змогу сконструювати інтерактивну графіку; Vlix, GoAnimate, Stupeflix, YouTube Video Editor, WeVideo, Magisto и Xtranormal - створити відео й інтегрувати його на YouTube; Xtranormal - випустити власний мультфільм.

Кожний крок слугує сходинкою до опанування засобів IKT, які є опорою для безперервного навчання. Зрозуміти, на якій стадії знаходяться знання школярів у режимі реального часу, дають змогу on-lineтести, розроблені в Google. Важливим є зростання кожного учня, тому нові ІКТ орієнтовані на персоналізацію школярів. Для реципієнтів важливо бачити свої досягнення, тому не зайвою $є$ змінна інформаційна стрічка перемог на блозі вчителя або сайті.

\section{4. Методика дослідження}

Виходячи із нагальних потреб освітнього процесу, під час експериментального навчання (формувальний етап) було докладено зусиль для формування внутрішньої й пізнавальної мотивації школярів через створення ситуацій успіху, розроблено завдання з літератури 3 використанням засобів ІКТ для старшокласників з метою активізації їхньої творчої активності й пізнання. У ході дослідження використовувалися Smart-технології, хмарні технології, геосервіси, технології Web 3.0. Вони оріснтовані на розвиток критичного мислення, створення інформатичного продукту, готовності до праці в умовах пошуку, в мережі Інтернет. У ході вивчення літератури старшокласниками було створено такі види робіт: буктрейлери, сторітейлінги, QR-квести, кластери, артскрайбінги, спільні презентації і документи, відеопоезії, комікси, відеоролики, інтелектуальні ігри, ментальні мапи, хмари слів, пазли, відеозапитання, інтерактивні дошки, була апробована відеотрансляція. Медіатексти учні систематизували за до-бою, літературними напрямами, стилями й угрупуваннями, творчістю письменників, а також визначали взаємозв'язки. Колажі з будь-якого формату не потребують особливих знань 3 програмування, тому сприяли розширенню світогляду, упливали на інтелектуальний розвиток учнів, оскільки інформаційна насиченість не має меж, а освіта $є$ дієвою. Звичайно, якість креолізованих текстів залежить від того, хто наповнює контентом персональний веб, його як інформаційної, так і літературної компетентностей. 
Аналіз та інтерпретація художніх творів з використанням засобів IКТ, джерел Інтернету відбувається з урахуванням особливостей їхньої жанрової й родової специфіки. Існують спільні ознаки різних творів: мова, настрій, образи. Розрізнення літературних жанрів відбувається за естетичною якістю (сатиричний, трагічний...), обсягом (повість, роман...), формою (оповідання, новела...). Ці ознаки впливають на організацію будови й змісту тексту. Для епічного твору характерним $\epsilon$ розподіл дії в часі та просторі, динаміка, тому його вивчення передбачає знайомство з випадком або історією життя героя / героїв. Виникає потреба в з'ясуванні причиново-наслідкових зв'язків, розв'язанні морально-естетичної проблеми, аналізі віртуальної дійсності, зображеної автором. Створення мікрофільму за мистецьким словом (програма «Kizoa») стане якнайдоречнішим, оскільки учні мають змогу продемонструвати місце подій, вчинки літературних героїв і їхні рухи (міміку, жести), акцентувати увагу на зовнішності та поглядах. Можливим стає створення веб-енциклопедії за твором, де школярі розміщують інтернет-посилання.

Прикладом $є$ участь десятикласників у проекті «Кайдашева сім'я» - енциклопедія народознавства», що спрямовує їхню пошукову діяльність на з'ясування спільних ознак національного характеру українців, їхнього побуту, предметів ужитку, кухні, одягу, мистецтва, звичаїв, обрядів і традицій. Реєстрація на YouTube, вступ до групи, створення власного літературно-інформатичного продукту (буктрейлеру), який стає промоушеном до твору, завантаження та обговорення його на сайті в он-лайн режимі уможливлює саморозвиток, активну взаємодію, виявлення світогляду, формує нестандартний спосіб мислення. Буктрейлери М. Якіна називає явищем масової культури, продуктом технологізації й комерції інформаційного й соціокультурного простору. Література й мистецтво виступають провідними елементами духовної культури, а з погляду потреб людини в діалозі на «вічні» запитання, їхнє створення виступає певним контентом для заповнення форми за визначеними правилами реклами й маркетингу [22]. Дослідження особливостей буктрейлерів, їхнього впливу на розвиток читацьких інтересів учнів; методичні основи створення буктрелерів та зразки медійної діяльності школярів запропоновано нами в статті «Компетентнісний підхід до викладання літератури з використанням хмарних 
технологій» [23]. Іронічні й гумористичні моменти було відображено в коміксах (ресурс «Ilovefreesoftware»).

Вивченння в 11 класі прозового твору «Зачарована Десна» О. Довженка передбачає ознайомлення старшокласників з іï автобіографічною основою. У нагоді стали школярам засоби IКТ, джерела Інтернету, які дали змогу порівняти двох ліричних героїв: малого Сашка і зрілу людину. Використання програми «РoowToon» уможливило подання спільних і відмінних рис образів персонажів у артскрайбінгу, а за допомогою програм «Paint» $\mathrm{i}$ «Adobe Fotoshop» сторити асоціативне полотно «Дитинство» й розмістити їх у колажі. Морально-етичні проблеми, порушені в кіноповісті, знайшли своє відображення у власних монологічних висловлюваннях, які учні розмістили на сторінках власного блогу, що стали меседжами, зверненими до реципієнтів.

Компаративний аналіз творів В. Винниченка «Момент» і Г. Косинки «В житах» передбачав значну підготовчу діяльність, у результаті якої реципієнти дійшли висновку, що життя складається з митей щастя й випробувань, постійного вибору й відповідей за раніше скоєні вчинки. Розповіді про історії нетривалого кохання в ризикованій для життя ситуації, спільні проблеми сенсу щастя людини, розчарування в нав'язаній ідеології, дисгармонії у внутрішньому й зовнішньому світах знайшли своє відображення в інфографіці («Piktochart») й QR-quest, a характеристику героїв у поєднанні з ілюстративним матеріалом розмістили на інтерактивних он-лайн дошках («Padlet», «Thinglink»).

Вивчення ліричного твору перебуває у взаємозв’язках з психолінгвістичним аналізом і сенсорним типом мисленням (за А. Плигіним), тому його аналіз та інтерпретація пов'язані з цілісним сприйманням і потребує спеціально організованої діяльності, що була б спрямована на вияв читацької реакції. Синтез учнівських вражень залежить від культури їхніх почуттів. Створення читачами власного поетичного твору й розміщення його в електронному журналі чи газеті уможливлює розуміння законів мистецтва, оволодіння теорією літератури, використання засобів літератури, створення настрою. Старшокласники здійснюють образні й чуттєві узагальнення шляхом порівняння з іншим літературним твором чи видом мистецтва. Проведення аналізу в єдності форми і змісту завдяки використанню алгоритмів і схем, засобів ІКТ поглиблює інтелек- 
туальну діяльність, сприяє формуванню літературної й інформаційної компетентностей, посилює переживання.

Неабияке враження на учнів справило вивчення творчості київських поетів-неокласиків (10 клас) та поетів-шістдесятників (11 клас). Філософічність, афористичність сонетів, вітаїзм, сповідальність поетичних творів було передано школярами у відеопоезіях. Крім літературної компетентності, що передбачала шліфування вміння виразно й усвідомлено читати вірші, виокремлювати їхні основні мотиви, стала можливою передача образності, почуття, урахування настрою, ритму поезій завдяки засобам IКТ. Інформаційна грамотність і культура стали в нагоді в ході створення відеопоезій, редагування (сервіс «YouTube Video Editor») й розташування медійних текстів у YouTube. Кількість перглядів свідчила про зацікавленість реципієнтів такою медіапродукцією, іiі інформаційну й естетичну значущість.

У процесі аналізу драматичного твору виникає потреба в засвоєнні його ознак. Ускладнюється цей процес через відсутність прямої авторської позиції, діалогічність викладу змісту, стислість у часі. Напруженість у розгортанні сюжету пов'язана зі стрімкістю, тому учням пропонується дослідити проблеми, відстежити взаємини героїв, роль реплік, монологів, діалогів і відтворити їх у ілюстраціях, асоціативних зв'язках, розігруванні епізодів драматичного твору, виявивши власну позицію до зображуваного. Фіксування мистецької гри учнів на відео посилює їхню творчу активність і враження від твору, уможливлює вияв розуміння читачами задуму автора.

Знайомство 3 драматичним твором у 10 класі «Мартин Боруля» I. Тобілевича і «Мина Мазайло» М. Куліша сприяло вияву творчості й акторської майстерності школярів. Свої інсценізації учні відзняли й порівняли з задумом автора, з'ясували: на скільки вдалося передати дух доби, сценічне втілення образів героїв, викрити бездуховність обивателів. Володіння інформаційними засобами уможливило монтаж зі спецефектами, що покращило сприйняття характеристики героїв не лише через діалоги, а й через відтворення національного колориту, засобів гумору. Створення ментальних карт (ресурси «Mindmeister», «Mindomo»,) покращило сприймання текстів творів, моральних цінностей і чеснот, які пропагує той чи інший письменник. Перевіряли засвоєння знань учні за допомогою відеозапитань («Zaption»), розроблених 
однокласниками. Наскрізними уміннями виявилися робота 3 інформацією, здійснення аналітико-синтетичної діяльності, вияв креативних здібностей, критичне мислення, здійснення планування, рефлексія.

Оцінювання здійснювалося за допомогою використання критеріїв, розроблених Г. Блумом: знання, розуміння, застосування, аналіз, синтез, а також маркерів оцінювання компетентностей В. Корольова: репродуктивне відтворення, репродуктивна алгоритмічна дія, продуктивна евристична дія, продуктивна творча дія.

\section{5. Результати дослідження}

Формувальний етап експерименту було проведено в 5 областях України. У ході його здійснення розроблено навчальну програму 3 української літератури з використанням ІКТ для школярів 10-11 класів, різнорівневі завдання для учнів, виконання яких демонструвало літературну й інформаційну компетентність старшокласників, віртуальні лекції й опорні картки за темами, проведено віртуальні екскурсії для можливості створення власних 3-D демонстраційних залів, розроблено інформаційні кейси з методичного забезпечення вчителів необхідним матеріалом з методики предмета.

Учні виконували завдання в гугл-класі, починаючи з напростішого використання ресурсів (Google документи, форми, таблиці, презентації) й умінь працювати з електронним каталогом бібліотек. Згодом завдання ускладнювалися, діти навчилися створювати медіатексти, розміщувати свої роботи в YouTube, брати участь у web-квестах на літературні теми. Кожна сторінка квесту була об'єднана гіперпосиланнями, що створювало враження мандрівки. За результатами квестів школярі готували звітні презентації за допомогою програм («Prezi», «Emaze»). Перешкодами на шляху до опанування Е-навчання ставали недостатня обізнаність учителів і учнів із новими видами IКТ, інтерфейсами сервісів, низька мотиваційна готовність і інформаційна компетентність учнів, але поступове зацікавлення IКТ, інформаційними ресурсами сприяло покращенню результатів.

Кожним учителем, який брав участь у експерименті, було створено блог / сайт, на якому розміщувалися колекції кращих робіт учнів, що сприяло обміну досвідом, інформацією. Ці блоги / сайти стали віртуальними лабораторіями, що надають допомогу в опануванні програ- 
мовим матеріалом 3 літератури реципіснтам, сприяють формуванню дослідницьких якостей, пізнавального інтересу, інформаційної культури. Крім того, була створена лабораторія для обдарованої молоді області з підготовки до участі в олімпіадах і конкурсах різного рівня. Використання елементів Е-навчання мало такі функції: моделювання віртуального середовища, об'єднання учнів у спільноти за інтересами й рівнем мотивації, приховане керівництво проектами. Розроблені учнями інтелектуальні ігри (програма LearningApps), он-лайн опитування дали змогу перевірити знання школярів за темами з літератури й зацікавити предметом, формувати інформаційну компетентність і пізнавальну активність, сприяли самоосвіті й безперервному навчанню.

Важливими успіхами на шляху до опанування сучасних ІКТ стали дистанційні курси для учнів, які з певної причини не могли відвідувати школу, віртуальні семінари з підготовки до олімпіад, державної підсумкової атестації й зовнішнього незалежного оцінювання, методичні рекомендації для вчителів 3 використання сервісів і смарт-дошок. Перемоги на різних етапах проведення конкурсів з предмета, успішне складання учнями вступних іспитів до університетів свідчать про значні досягнення на шляху в опануванні літературною й інформаційними компетентностями. Це сприяє збереженню контингенту в школах у старшій ланці, оскільки учні виявляють бажання продовжувати навчання в ЗНЗ. Приклади робіт старшокласників можна побачити за електронною адресою: https://lessons555.blogspot.com/. Вони сприяють залученню до проектів і школярів середньої ланки, які більш активно працюють, намагаються досягти завчасно запланованого позитивного результату. Це дало змогу проводити традиційне навчання літератури в поєднанні з новаційним, очне й дистанційне (рис. 1).

Очна й дистанційна форми навчання $\epsilon$ ефективними за умови їхнього постійного взаємозв'язку й узгодження між собою. За результатами навчальних досягнень учнів спостерігалося поліпшення якості навчання в експериментальних класах. 3 метою підтвердження наводимо результати кінцевого анкетування та тестування після формувального етапу експерименту (табл. 1) та розрахунки, які свідчать про те, що рівень ІК-компетентності учнів експериментальних класів збільшився в порівнянні з рівнем у контрольних класах $\left(\lambda\right.$ емп $=3,87>\lambda \kappa р=1,36 ; \varphi^{*}$ мп $=4,11>\varphi^{*}$ кр $\left.=2,31\right)$. 


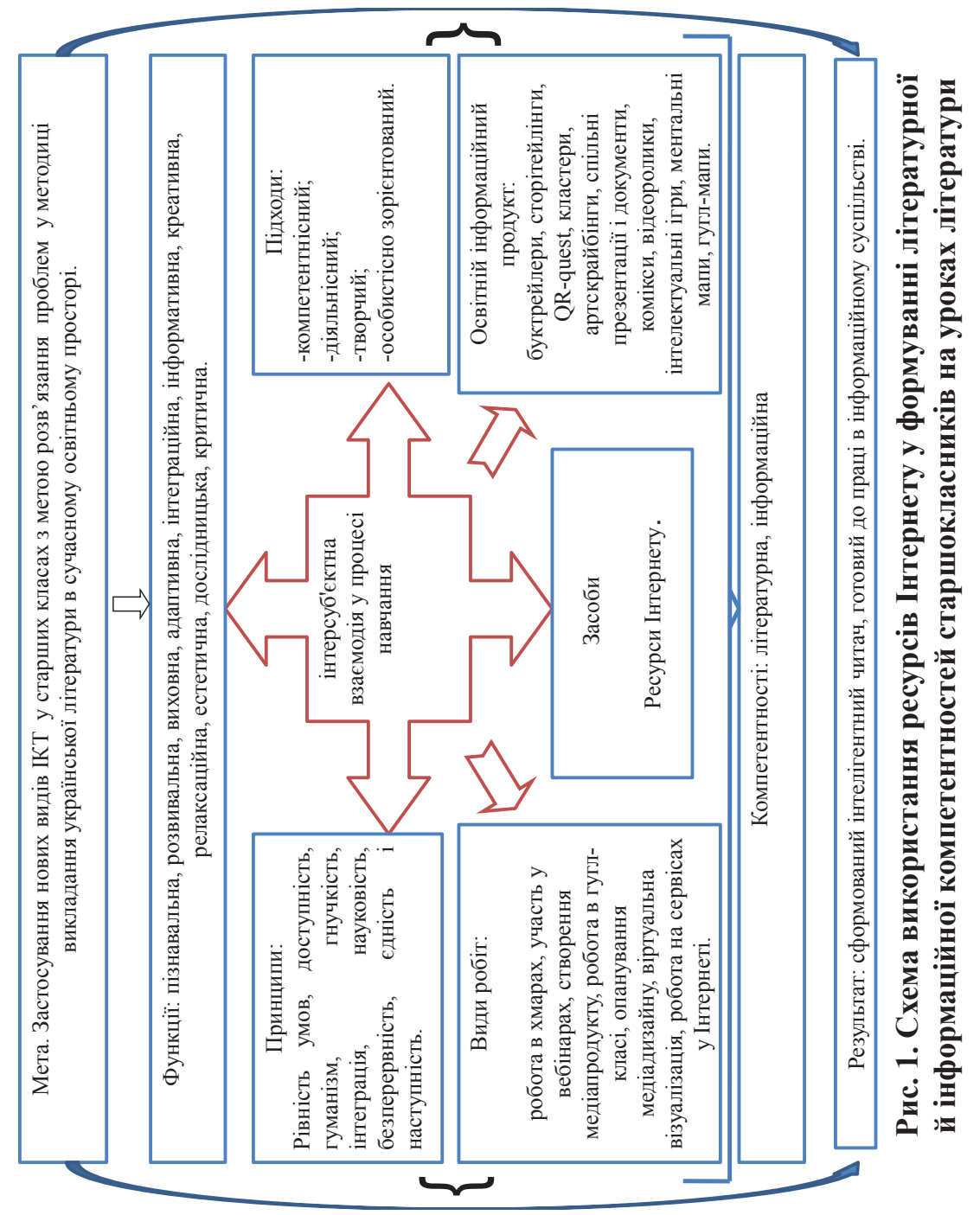


Завдяки використанню методів статистичної обробки та порівняльного аналізу маємо результати початкового та підсумкового зрізів, які підтвердили позитивну динаміку набуття учнями інформаційної компетентності (табл. 1).

Таблиця 1

\section{Результати експертного опитування учнів} контрольних та експери-ментальних класів (кінцевий етап формувального експерименту)

\begin{tabular}{|c|c|c|c|c|c|}
\hline \multirow{2}{*}{ ЕК } & \multicolumn{2}{|c|}{$\begin{array}{c}\text { С ефект відповідно } \\
\text { до аналізу анкет }\end{array}$} & \multicolumn{2}{|c|}{$\begin{array}{c}\text { Немає ефекту відповідно } \\
\text { до аналізу анкет }\end{array}$} & \begin{tabular}{c} 
Загальна \\
кількість \\
\cline { 2 - 5 } \\
Кеспондентів
\end{tabular} \\
\hline КК & 173 & 69 & 76 & 31 & 249 \\
\hline
\end{tabular}

Динаміка змін показника (ЕК, КК) відобразила позитивні тенденції ком-петентнісного розвитку учнів за кількістю респондентів щодо сформованості рівнів інформаційної компетентності). Школярами як представниками нового мобільного покоління було підтверджено, що завдання творчого спрямування для них більш цікаві. Так, можливість використання графічного редактора вважають позитивним 45\% учнів, розробку інтелектуальних ігр та інтерактивних завдань (веб-ресурс «LearningApps») - 95\% респондентів; можливість створювати артскрайбінги (веб-ресурс «РoowToon») - 78\%, буктрейлери, відеопоезії - 81\%, інфографіку - 64\%, ментальні карти - 85\%, Googlкарти $-72 \%$, брати участь у творенні Googl-форм, спільних презентацій $-83 \%$, дизайні тегових хмар - 75\%, веб-квестів - 52\%, ребусів та кросвордів - 81\%, інформаційнних дошок (сервіс «Padlet») - 65\%. Переваги використання нових засобів ІКТ у навчальному процесі, можливість обирати рівень складності завдань, демократичність оцінювання, доступність інформації, різноманітність ресурсів для вияву творчості й когнітивної складової навчання, спілкування в соцмережах з освітньюю метою надають другого дихання традиційному навчанню. На констатува-льному етапі експерименту сформованість інформаційної й літературної компетентності значно зросли в порівнянні з початком формувального етапу експерименту (табл. 2). 
Таблиця 2

Результати обробки експериментальних даних

(експериментальні класи)

\begin{tabular}{|c|c|c|c|c|c|c|c|}
\hline \multirow[b]{3}{*}{ Долі одиниці } & \multicolumn{7}{|c|}{ Рівні } \\
\hline & \multicolumn{2}{|c|}{ Високий } & \multicolumn{2}{|c|}{ Достатній } & \multicolumn{2}{|c|}{ Середній } & \multirow{2}{*}{\begin{tabular}{|c|} 
Низький \\
0,0183 \\
\end{tabular}} \\
\hline & 0,2038 & 0,2932 & 0,6668 & 0,6380 & 0,1112 & 0,070 & \\
\hline $\begin{array}{l}\text { Кутове } \\
\text { перетворення }\end{array}$ & 0,9059 & 1,0909 & 1,7086 & 1,6636 & 0,6675 & 0,5256 & 0,2720 \\
\hline $\begin{array}{l}\text { Спостережуване } \\
\text { значення критерію } \varphi^{*}\end{array}$ & \multicolumn{2}{|c|}{1,3049} & \multicolumn{2}{|c|}{0,3174} & \multicolumn{2}{|c|}{1,0009} & 1,9197 \\
\hline $\begin{array}{l}\text { Ймовірність спо- } \\
\text { стережуваного зна- } \\
\text { чення за критерієм } \\
\text { Стьюдента }\end{array}$ & \multicolumn{2}{|c|}{0,1936} & \multicolumn{2}{|c|}{0,7513} & \multicolumn{2}{|c|}{0,3182} & 0,0562 \\
\hline $\begin{array}{l}\text { Значущість, з якою } \\
\text { приймається гіпо- } \\
\text { теза про наявність } \\
\text { суттєвих змін в рів- } \\
\text { нях сформованості }\end{array}$ & \multicolumn{2}{|c|}{0,8066} & \multicolumn{2}{|c|}{0,2488} & \multicolumn{2}{|c|}{0,6819} & 0,9436 \\
\hline
\end{tabular}

Умовами, завдяки яким навчання стало успішним стали: забезпечення засобами навчання на уроці (мобільні пристрої, ноутбуки, i-Pod), використання Smart-дошок; доступність сервісів незалежно від місця проживання; налагодження партнерської узаємодії між учнями й учителями, розуміння суб'єктами освіти важливості використання Інтернету як яскравого прикладу не лише інтертекстуальності, а й засобу вияву творчості й моделювання; тісного взаємозв'язку інформаційно-комунікаційних технологій з розвитком і збагаченням читацького досвіду й набуття компетентностей учнів; підвищення якості освітніх послуг, рівня викладання предмета вчителями й позбавлення їх страхів щодо використання нового й маловідомого; соціалізації та психологічної підтримки.

Проведення формувального етапу експерименту дало змогу констатувати той факт, що читачам необхідно було навчитися організовувати свою діяльність, щоб відчути красу виучуваного твору, власне зростання. Важливе місце в розв'язанні суперечностей посіли умови, за яких навчання стало успішним, налагоджено соціальні зв'язки між учителем та учнями. 
Встановлено, що одноманітна робота, що проводилася раніше на уроках літератури, давалася взнаки: старшокласникам на початку формувального етапу експерименту було складно призвичаїтися до нових умов роботи, бо виникали ускладнення в іiі організації. Згодом наполеглива спільна праця привела до підвищення рівня мотивації в навчанні, аналітичних дій, появі бажання нестандартно використовувати свій читацький досвід.

Передбачення результатів діяльності дало змогу учням зробити меншу кількість помилок, уникнути недоліків, зрозуміти авторські орієнтири. Чітке уявлення майбутнього літературно-інформатичного продукту уможливлювало моделювання його, створення умов для швидкої реалізації планів. Орієнтир на можливі досягнення навчив раціональним прийомам діяльності, сформував в учнів-читачів експериментальних класів здатність адекватно оцінювати свої сили, виправляти помилки, розвивати позитивні особистісні якості, моральну відповідальність.

\section{6. Висновки та перспективи подальших досліджень}

Аналіз теоретичних джерел підтвердив наявність проблеми формування інформаційної компетентності реципієнтів і ключових положень для іiі розв'язання, а саме: мотиваційна готовність, безперервне навчання, активна самоосвіта, знаходження сенсу в електронному навчанні в мережі, використання ресурсів Інтернету, уміння працювати з інформацією, інтегративна взаємодія суб'єктів навчання. 3'ясовано зміст поняття «інформаційно компетентна особистість», під яким розуміємо особистість здатну до організації нових форм співпраці з іншими людьми на базі мікропроцесорної техніки, різних видів діяльності, підготовлена до життя в соціумі, обізнана з ІКТ, методами обробки інформації, спроможна удосконалювати свою діяльність, що спиратиметься на сукупність професійних, методологічних, загальнокультурних знань та практичних умінь.

Проведене дослідження засвідчило важливість і актуальність електронного навчання та застосування Е-ресурсів у шкільній практиці в процесі викладання української літератури; розкрито особливості їхнього використання. Здійснено акцент на Е-навчанні, яке $є$ прогресивним і перспективним, відповідає сучасним освітнім вимогам, дає 
змогу вивчати матеріал у сприятливому для учнів темпі. Розкрито можливості Е-навчання як образу мислення самостійного творення концепцій, розв'язання практичних завдань і демонстрації знань. Схарактеризовано види діяльності на уроках літератури з використанням засобів IКТ, що уможливлюють розкриття когнітивної й творчої складових навчального процесу, їхній вплив на формування літературної й інформаційної компетентностей. Визначено, що в процесі залучення школярів експериментальних класів до предметної діяльності з використанням Smart-технологій, хмарних технології, геосервісів, технологіï Web 3.0, спостерігаються значні зрушення в по-зитивний бік щодо формування компетентностей, інформаційної культури, підвищення мотивації, зацікавленості предметом. Подано використання ресурсів Інтернету з метою формування інформаційної компетентності старшокласників на уроках літератури в структурованому виді, узято до уваги їхні можливості та практичну орієнтованість завдань для підвищення якості освіти завдяки оновленню змісту навчання. Узагальнено умови, завдяки яким навчання стало успішним. Результати експериментального навчання, опитування школярів підтвердили висунуту гіпотезу про дієвість використання ресурсів Інтернету, їхні переваги для підвищення рівня компетентностей старшокласників.

Таким чином, пропоноване дослідження не вичерпує всіх аспектів порушеної проблеми. Предметом подальших перспективних розвідок можуть стати розробка пілотних проектів у сфері Е-навчання, забезпечення якості освіти при застосуванні е-навчання в інклюзивній освіті.

\section{Список літератури:}

1. Баловсяк Н.Х. Структура та зміст інформаційної компетентності майбутнього спеціаліста. URL: http://www.ii.npu.edu.ua/files/Zbirnik_KOSN/11/30.pdf (дата звернення: 17.02.2020).

2. Родигіна I. Модель компетентнісно спрямованого педагогічного процесу. Моделі компетентного випускника 12-річної школи: сутність, пріоритети, пошук відповідей на виклики XXI століття : матеріали Всеукр. наук.-пошук. конф. (КиївДонецьк, 16-17 травня 2007 р.). Донецьк : Наукове видання, 2007. Т. 1. С. 105.

3. Савченко О. Формування ключових і предметних компетенцій молодших школярів: дидактико-методичні аспекти. Дайджест 2. Донецьк : Каштан, 2012. $141 \mathrm{c}$.

4. Андресен Бент Б. Мультимедиа в образовании: спец. учебн. курс : Информационные технологии в образовании. Москва : Дрофа, 2007. 224 с. 
5. Wanner T. Enhancing Student Engagement and Active Learning through Just-in-Time Teaching and the use of PowerPoint. International Journal of Teaching and Learning in Higher Education. 2015, Vol. 27, no. 1, pp. 154-163. URL: https://files.eric.ed.gov/fulltext/EJ1069796.pdf (дата звернення: 17.12.2019).

6. Зубарев К. Информационно-педагогическая компетентность студентов педагогических вузов. Учитель. 2008. № 1. С. 88-90.

7. Лебедева М.Б., Шилова О.Н. Что такое ИКТ-компетентность студентов педагогических университетов и как её формировать. Информатика и образование: научно-метод. журнал. 2004. № 3. С. 95-100.

8. Wankel Charles st., Kingsley Jan. Higher education in virtual worlds: teaching and learning in second life. United Kingdom : Emerald Group Publishing Limited: Howard House, 2009. P. 259.

9. Siemens G. Connectivism: A Learning Theory for the Digital Age. 2004. URL: http://www.devrijeruimte.org/content/artikelen/Connectivism.pdf (дата звернення: 20.02.2020).

10. Siminson M., Thompson A. Educational Computing Foundations / Siminson, M. New York : MacMillan College Publishing Company, 1994. P. 467.

11. Heinich R. Instruction Media and the New Technologies of Instruction / Heinich R., Molenda M., Russell J.D. N.Y.: Macmillan Publishing Company, 1993. 460 p.

12. Subramanian K. How Cloud Computing Can Help School Education? 2009. URL: https://www.cloudave.com/1790/how-cloud-computing-can-help-schooleducation.doc (дата звернення: 27.01.2020).

13. Sultan N. Cloud computing for education: A new dawn? International Journal of Information Management. 2010. Vol. 30(2). pp. 109-116.

14. Кухаренко В., Нестеренко В., Решетник Н., Сіренко М., Товажнянський Л. Концепція розвитку електронного (е-) навчання в НТУ «ХПІ» на 2009-2016 роки. URL: http://cde.kpi.kharkov.ua/cdes/New/Conception_eL.pdf (дата звернення: 27.01.2020).

15. Kabassi K., Virvou M. Using Web Services for Personalised Webbased Learning. Educational Technology \& Society. 2003. Vol. 6(3). pp. 61-71. URL: http://ifets.ieee.org/periodical/6_3/8.html.doc (дата звернення: 20.02.2020).

16. Морковина Е.Ф. Развитие информационной компетентности студента в образовательном процес се : автореф. дис. на соискание учёной степени кандидата педагогических наук: 13.00.01.Оренбург, 2005. 21 с.

17. Desimone L.M., Porter A.C., Garet M.S., Yoon K.S., Birman B.F. Educational Evaluation and Policy Analysis, 2002. Vol. 24, No. 2. pp. 81-112. URL: http://outlier.uchicago.edu/computerscience/OS4CS/landscapestudy/resources/ Desimone,Porter.pdf (дата звернення: 23.02.2020).

18. Quaye S.J., Harper S.R. Nine themes in campus racial climates and implications for institutional transformation. URL: https://scholar.google.ru/citatio ns? user=qqxn5B4AAAAJ\&hl=en (дата звернення: 12.12.2019).

19. Clevenger-Bright M., Hays K., Henricksen L., Hlebain D., Maglalang J., Packard M., Pursch Cornforth K., Raftus D. Service learning. URL: http:/www.washington.edu/teaching/teaching-resources/engaging-studentsin-learning/service-learning/ (дата звернення: 15.12.2019). 
20. Биков В., Кухаренко В. Дистанційний навчальний процес. URL: http://bcoreanda.com/ShowObject.aspx?ID=163 (дата звернення: 19.03.2014).

21. Болдачев O. WEB 3.0. WEB 3.0. От сайтоцентризма к юзероцентризму, от анархии к плюрализму. URL: https://habr.com/post/256083/ (дата звернення: 27.01.2020).

22. Якина Л.Н. Буктрейлер - культурное явление? Современные культурные практики. 2014. С. 42-45.

23. Паламар С., Назаренко Л. Компетентнісний підхід до викладання літератури з використанням хмарних технологій. Вісник Луганського наиіонального університету імені Тараса Шевченка: Педагогічні науки. 2018. № 3(137). С. 102-109.

\section{References:}

1. Balovsyak N.Kh. Struktura ta zmist informatsiinoi kompetentnosti maibutnoho spetsialista [Structure and content of information competence of the future specialist]. (electronic journal). Available at: http://www.ii.npu.edu.ua/files/ Zbirnik_KOSN /11/30.pdf (accessed: 22.01.2020).

2. Rodigina I. (2007). Model kompetentnisno spriamovanoho pedahohichnoho protsesu [Model of competently directed pedagogical process]. Proceedings of the «Models of competent graduate of 12-year school: essence, priorities, search of answers to the challenges of XXI century» (Ukraine, Kyiv-Donetsk, 16-17.05. 2007). Donetsk: Scientific edition, P. 105.

3. Savchenko O. (2012). Formuvannia kliuchovykh i predmetnykh kompetentsii molodshykh shkoliariv: dydaktyko-metodychni aspekty. Daidzhest 2. [Formation of key and subject competences of younger students: didactic-methodical aspects. Digest 2]. Donetsk: Kashtan, 141 p. (in Ukrainian)

4. Andersen Bent B. (2007). Multymedya $v$ obrazovanyy [Multimedia in Education]. Moscow: Information Technology in Educationnces, 224 p. (in Russian)

5. Wanner T. (2015). Enhancing Student Engagement and Active Learning through Just-in-Time Teaching and the use of PowerPoint. International Journal of Teaching and Learning in Higher Education (electronic journal), vol. 27, no. 1, pp. 154-163. Available at: https://files.eric.ed.gov/fulltext/EJ1069796.pdf (accessed: 25.01.2020).

6. Zubarev K. (2008). Ynformatsyonno-pedahohycheskaia kompetentnost studentov pedahohycheskykh vuzov [Information and pedagogical competence of students of pedagogical universities]. Teacher, vol. 1, pp. 88-90.

7. Lebedeva M.B., Shilova O.N. (2004). Chto takoe YKT-kompetentnost studentov pedahohycheskykh unyversytetov y kak eyo formyrovat [What is the ICT competence of students of pedagogical universities and how to form it]. Computer Science and Education: Scientific Method. Journal, vol. 3, pp. 95-100.

8. Wankel Charles st., Kingsley Jan. (2009). Higher education in virtual worlds: teaching and learning in second life. United Kingdom: Emerald Group Publishing Limited: Howard House, $259 \mathrm{p}$.

9. Siemens G. (2004). Connectivism: A Learning Theory for the Digital Age. (electronic journal). Available at: http://www.devrijeruimte.org/content/artikelen/ Connectivism.pdf (accessed: 26.12.2019). 
10. Siminson M. (1994). Educational Computing Foundations. New York: MacMillan College Publishing Company, $467 \mathrm{p}$.

11. Heinich R. (1993). Instruction Media and the New Technologies of Instruction. New York: Macmillan Publishing Company, $460 \mathrm{p}$.

12. Subramanian K. (2009). How Cloud Computing Can Help School Education? (electronic journal). Available at: https://www.cloudave.com/1790/ how-cloud-computing-can-help-school-education.doc (accessed: 30.10.2019).

13. Sultan N. (2010). Cloud computing for education: A new dawn? International Journal of Information Management, vol. 30(2), 109 p.

14. Kukharenko V., Nesterenko V., Reshetnik N., Sirenko M., Tovazhnyansky L. (2016). Kontseptsiia rozvytku elektronnoho (e-) navchannia v NTU "KhPI» na 2009-2016 roky [The concept of development of e-learning in NTU «KPI» for 2009-2016] (electronic journal). Available at: http://cde.kpi.kharkov.ua/cdes/New/ Conception eL.pdf (accessed: 22.01.2020).

15. Kabassi K., Virvou M. (2003). Using Web Services for Personalized Web-Based Learning. Educational Technology \& Society. (electronic journal), vol. 6(3), pp. 61-71. Available at: http://ifets.ieee.org/periodical/6_3/8.html.doc (accessed: 19.01.2020).

16. Morkovina E.F. (2005). Razvytye ynformatsyonnoi kompetentnosty studenta $v$ obrazovatelnom protsesse [The development of the information competence of the student in the educational process] (PhD 13.00.01 «General Pedagogy, History of Pedagogy and Education»), Orenburg.

17. Desimone L.M., Porter A.C., Garet M.S., Yoon K.S., Birman B.F. (2002). Educational Evaluation and Policy Analysis (electronic journal), vol. 24, no. 2, pp. 81-112. Available at: http://outlier.uchicago.edu/computerscience/OS4CS/ landscapestudy/resources/Desimone,Porter.pdf (accessed: 15.12.2019).

18. Quaye S.J., Harper S.R. Nine themes in campus racial climates and implications for institutional transformation (electronic journal). Available at: https://scholar.google.com/citations?user=qqxn5B4AAAAJ\&hl=en (accessed: 23.12.2019).

19. Clevenger-Bright M., Hays K., Henricksen L., Hlebain D., Maglalang J., Packard M., Pursch Cornforth K., Raftus D. (electronic journal). Available at: http://www.washington.edu/teaching/teaching-resources/engaging-students-inlearning/service-learning / (accessed: 17.01.2020).

20. Bykov V., Kukharenko V. Dystantsiinyi navchalnyi protses [The distance learning process] (electronic journal). Available at: http://bcoreanda.com/ ShowObject.aspx?ID=163 (accessed: 12.02.2020).

21. Boldachev O. WEB 3.0. Ot saitotsentryzma $k$ yuzerotsentryzmu, ot anarkhyy $k$ pliuralyzmu [WEB 3.0. From site-centrism to south-centrism, from anarchy to pluralism]. (electronic journal). Available at: https://habr.com/post/256083/ (accessed: 23.12.2019).

22. Yakina L.N. (2014). Buktreiler - kulturnoe yavlenye? [Buktreiler - a cultural phenomenon?]. Ekaterinburg: Contemporary Cultural Practices, pp. 42-45. (in Russian)

23. Palamar S., Nazarenko L. (2018). Kompetentnisnyi pidkhid do vykladannia literatury z vykorystanniam khmarnykh tekhnolohii [Competent approach to literature teaching using cloud technologies]. Bulletin of Lugansk Taras Shevchenko National University: Pedagogical Sciences, vol. 3(137), 10 p. 